\title{
YELLOW CASSAVAS, PURPLE BANANAS
}

\author{
EURIDICE CHARON CARDONA ${ }^{1}$
}

\begin{abstract}
Señora, everything is availablehere, even yellow cassava. I al so bought some purple bananas some time ago ... I am sure that in Cuba, those things are not available now. This is heaven ... How long is it since you have eaten purple bananas, señora? ${ }^{2}$
\end{abstract}

T hese words of a Cuban migrant, who had been living in A ustraliafor nearly 30 years, reflect his joy at being able to havesomething that peoplein thecountry of origin used to enjoy. But they also reflect the irony that products like these, which this migrant used to eat a long time ago in his homeland, are no longer available there, yet are available in his acquired home country of Australia. There is loss and re-encounter in this story, but in a different setting and in an inverse order. To a certain degree, this story shows why some Cuban migrants decided to make Australia their home. However, the story here goes beyond the simple act of eating. It is about the love that Cubans have for their national cuisine, and their expressions of identity through this aspect of their national culture. This is illustrated through the personal accounts reviewed below.

This paper explores the relevance of food in the maintenance and re-creation of Cuban identity amongst a group of migrants who have been living in Australia for nearly 30 years. Through this exploration it is suggested that the existence of a substantial ethnic food market in A ustralia has facilitated Cuban migrants' maintenance of their previous eating habits, and through this their sense of Cuban identity.

\section{CUBAN MIGRANTSIN AUSTRALIA}

The political, economic and social changes experienced in Cuba over thelast forty years have promoted several waves of migration, extending largely to neighbouring countries, but also to other more geographically, culturally and/ or historically distant countries. There are, however, smaller groups who live in other Latin American countries, as well as Canada, the Middle East, Russia, Africa and Australia. ${ }^{3}$

The first numerous group of Cuban migrants to arrive in A ustralia came in the early 1970s. Themajority of this group came from Spain through an assisted passage program. Amongst those arriving at this time, some had earlier migrated to the US. This first group, 
coming from Spain and the United States, was mainly composed of Cuban families of Spanish descent.

The second migration intake took place in the 1980s, corresponding to the 'M ariel boatlift' in which approximately 125000 Cubans left Cuba for theUS. ${ }^{4}$ The Australian government admitted some Cuban migrants at this time through a refugee scheme, after interviewing them in Peru and the United States. ${ }^{5}$ Liketheir counterparts in the US, this group of 'M arielitos' in Australia, mainly composed of males, was stereotyped by the local media as 'delinquents, blacks and people who didn't intend to stay in Australia and were planning to leave for the US'. ${ }^{6}$

Cuban immigrants who havearrived in A ustralia during the last 15 years have tended to enter through the family reunion component of Australia's immigration policy. Some of these migrants are married to Latin A mericans, Eastern Europeans, people from the Middle East and south-east Asia, who studied or worked in Cuba or in some Eastern European countries. Other Cubans are married to people of Australian background. On this basis, the 1996Census of theAustralian population found 231 Cuban-born people living in New South Wales. ${ }^{7}$

\section{A NOTE ON THE INFORMATION GATHERING PROCESS}

This work is a part of a major research study of Cuban migration in NSW, Australia. As noted above, therearefewer than 250 Cuban-born people living in NSW. Due to this small number, it was not possible to contact people through official channels such as Migrant Resource centres or other institutions working with local ethnic groups. Given these constraints, I first contacted some Cuban migrants by attending social activities of the Latin American community in Sydney. Building on these initial contacts with members of the Cuban community, I was invited to some private gatherings and social events. The main methods used for collecting the information for this work were participant observation and informal interviews.

\section{BEING 'CUBAN 'THROUGH FOOD}

Going through my fiel dwork notes, I was immediately struck by the frequency of evocations of food, especially in the household settings. Indeed, food soon emerged as an important part of thelives of Cuban migrants whom I met. This was no doubt linked, in part, to my being obliged to eat or drink something during my social visits which, in turn, highlighted and reflected theimportance of food. A dditionally, it was notable that many of the houses that I visited displayed very few visible symbols or markers of the ethnicity of their Cuban inhabitants. Indeed, some of thesehouses are not very different from the middleclass suburban Australian house, with a flower bed garden outsideand expensive leather lounge inside. The display of a small Cuban flag in themiddleof a dining room table, or a smaller version of it as a fridgemagnet, was in somecases theonly visible symbol of Cuba in those houses.

As soon as the guest arrives heor she is invited to a short black and sweet Cuban style coffee. And then, immediately, the stories start to be told about which coffee 'nearly has a Cuban flavour', whereto get it, how long it needs to be roasted and so on. The seemingly typical, middle-class, A ustralian suburban house begins its trans- 
formation. The aroma of the coffee and the continuous invitations to stay longer for lunch and/ or dinner, or at least a small snack, have 'Cubanised 'thehouse.

Experiences like these led me to conclude that, for this group of Cubans, the maintenance of their previous food habits constitutes a way in which they try to reinforce and re-create their identity. Ghassan Hage suggests that this type of recreation should be seen as positive nostalgia, arguing that 'the positive nostalgia does not necessarily involve a desire to "go back"', but promotes the desire of "being there here"'. ${ }^{8}$ Hage adds that migrants tend to reproduce or borrow their previous 'imaged homely experiences' in themost diverseways and situations, such as living in a suburb surrounded by people from the same language, or 'surrounding oneself with culturally pleasing objects, smells and sounds'. ${ }^{9}$ Moreover, Hage claims that when migrants borrow these previous homely experiences they are better equipped to confront life in the new country, and to make better use of the opportunities offered to them by thenew society. ${ }^{10}$ The practices of food consumption and production in migrant homes, as found amongst these Cuban migrants, are good examples of these processes.

During the fieldwork I encountered many similar situations in which Hage's arguments were directly applicable. For example, a Cuban man who has been living here for more 30 years, after first migrating to Spain, commented to me:

When wearrived, we lived in a hostel, in Villawood. We were not allowed to cook there. Every day wewerefed riceand smelly lamb. I didn't like it, because here people do not marinate meats for a long time. However, a few weeks after our arrival someone gave us a small electric stove, so we decided to prepare our own food. We bought and took home some chicken and rice. Marta prepared a big pot of arroz con pollo [chicken and rice].

$\mathrm{H}$ is face lit up at this point. He continued:

It wasmorechicken than ricein the pot. M e
di una hartada! [I atea hugeamount!]. I even
licked my fingers. It was so good ...
delicious. This was one of my happiest
moments in Australia. I wasso happy that I
told her [hiswife] after eating: 'Marta, I will
stay here! Here, in Australia!'

I laughed and inquired further whether the chicken and rice made him stay in Australia? Heproudly replied: 'Yes, what el se do you need?'

This encounter illustrates how important it was for this man to be able to eat the food that he was used to in his homeland. It is also interesting how this 'previously homely experience' helped him to decide to stay permanently in Australia. Two other issues need to be considered here. First, the family in this passage left Cuba in the 1970s, when the scarcity of some foods and traditional products was becoming moreacute, with meats in particular suffering a considerable reduction. Theintroduction of food rationing also acted as a push factor in many migrant cases. ${ }^{11}$ In this context we can understand why the informant highlights things like there being 'more chicken than rice in the pot'. Second, in Cuba chicken and rice was traditionally considered a 'Sunday dish', or a dish that must becooked when guests or visitors are coming to the house. However, this tradition has declined in Cuba.

It should be pointed out that the 
Cuban diet and food habits havechanged substantially over the last century, particularly after the triumph of 1959 Revolution. TheUSembargo, and thelack of hard currency of the Cuban government, directly affected the acquisition of some spices and products used in traditional Cuban cuisine. As a result some of the most traditional plates of Spanish or Caribbean origin have nearly disappeared from the daily and festive Cuban cuisine in contemporary times. This has also impacted on the nationally favoured dishes. As noted previously, before 1959, arroz con pollo and tostones (fried green bananas) were the standard Sunday dinner. Today it is likely to be arroz con pollo, or black beans with rice, or any other dish. However, onefact that hasn't changed over the years is the act of leaving the 'protein meal' of meat or fish, or the 'best' food, for the weekends or special occasions when the family gets together.

In contrast to this contemporary reality in Cuba, I found that the diet of the oldest Cuban migrants in Australia has only changed slightly, although some of them, due to their age, have become more health conscious about their diet. For example, in the catering for some social activities, Cubans are keen to include an Argentinian asado (barbecued beef) or Uruguyan sweets made of filo pastry and caramel, both of which are popular in Cuba. In the household situation only slight changes can be perceived over the extended period that the Cuban migrants have been in Australia. Oncel remarked to a group of Cuban women that I admired how little their diet had changed after such a long time. Some of them started to blametheir husbands for not being open to innovations and change in the kitchen.
They al so complained that their husbands wanted to eat 'rice and beans' everyday. However, these women pointed out that with their children and grandchildren the case was different. They didn't want to eat 'hard food' or (Cuban food), but only chucherias (snacks and fast food). The women disapproved of this tendency. ${ }^{12}$

We can see here the ambiguity in the attitudes of these Cuban women. On one level, they blamed their partners for not wanting to try dishes from a different cuisine but, at the same time, they didn't agree with a complete change of eating habits for their children, from the traditional Cuban diet to fast food products. This example highlights the expected diversity amongst age groups in relation to food. Additionally, it can be argued that this is also used to differentiatethemselves fromother ethnic groups, in thesensethat themaintenance of food habits also serves as a selfassurance marker of their identity, and a divider between them and 'others'. For example, while an informant was telling me about her experiences with an Australian neighbour who was an elderly person, she remarked several times:

You know ... they [Australians] do not feed themselves properly. They like vegetables, fruit and 'watery' soups. This isn't food. So, I always used to tell my neighbour that she should eat real substantial food.

When I asked her what shemeant by that she replied:

I mean ... I mean rice, meat, and beans. I mean that sheneeds to havehot milk with chocolate in the afternoons.

The point hereis not so much the content 
of the diet pattern proposed by the informant, but theway in which food acts as a marker of ethnic belonging.

On another level, the eating habits of this group of migrants are also used by other groups, especially other Spanish speaking groups, to stereotypeCubans as sweet toothed (i.e. big sugar consumers), rice eaters, chicken lovers and coffee drinkers. In a social barbecue held in La Casa Latina at Marrickville community centre in Sydney last year, a South American cook told me that when hehas Cuban customers he usually cooks chicken because this is 'what Cubans like. They do not like slightly cooked meat, especially beef.' The same person, together with other South A merican people, questioned my identity becausel do not drink coffee. Heloudly exclaimed: 'Ah, here is a Cuban who doesn't drink coffee!' It should benoted that I encounter similar responses whenever I visit the house of a Cuban migrant.

During my fieldwork, I noticed that Cubans tend to include in or exclude someone from their ethnic group, based on their behaviour when serving or eating food. This can be seen in the story recounted by a Cuban woman about her visit to a restaurant co-owned by a fellow country person. Some of her impressions when she was served included the following:

When they brought us the food, I was astonished! Everything was very small. You could count the pieces of vegetables, and the two small pieces of steak ... terrible! It was so small. I thought that they were closing because they weregoing bankrupt for the lack of customers. They servetoo little. Then I thought: 'What sort of Cuban is this? Cubans are generous with food. They always serve a lot.'
This informant tried to assuremethat the restaurant's owner had 'learned this custom elsewhere. This was not Cuban.' On another occasion, a different Cuban informant made some comments about an invitation shehad received to a party. Shewas outraged because shewas asked to bring a plate, emphasising to me:

WherehaveCubans learned thesecustoms?
When in Cuba did you ever go to a party
and bring food? If you arethehostyou need
to invite people and serve them, you are
inviting them to your house. I never saw
that there, even during thedifficult times.
It's ridiculous and is not Cuban!

It is interesting how food is used to question somebody's ethnic identity in these situations. Additionally, the act of negating the ethnic affiliation of those people, and highlighting their newly acquired habits, shows that the informants have a set of concepts and images about how someonecan be Cuban in relation to food, or morespecifically how a Cuban host is 'supposed to be' in relation to food.

Finally, it is important to highlight that the low numbers and loose spatial distribution of the Cubans in NSW are factors that are likely to lead members of this ethnic group to reinforce their identity through something like their previous national cuisine. The Cuban migrants are rarely identified by others as Cuban, the closest tending to be Latin American due to their Spanish accent, sinceexternally they do not look different from other Latinos, Southern Europeans or Africans. Given this, their eating habits are apparently a unique external marker that help people to check out and contest who is an authentic Cuban and who is not; what is Cuban and what is not. 
THE MULTICULTURAL ETHNIC MARKET AND THE RE-CREATION OF THE 'CASI CU BANO' (NEARLY CUBAN)

A general overview of the Cuban cuisine makes it easier to understand how Cuban migrants in Sydney have been able to recreate and maintain their previous food habits. Thedifferent migration wavesthat swept the Caribbean region over centuries haveinfluenced thecultureand the culinary habits of the region. As with any cuisine in the Caribbean region, the Cubans have taken elements from the local Amerindian traditions, Spanish, African and Chinese cookeries. The Cuban cuisine is a blend of Spanish and African ways of cooking applied to tropical ingredients and products. This mix took place when the Spanish colonisers made African slaves housemaids to cook 'Spanish'dishes with imported and locally available products. The increasing immigration of Chinese indentured workers added other flavours to the Cuban cuisine. Some dishes of the Spanish and Chinese cuisine are so entrenched in Cuba that they are consistently included in Cuban cookbooks. For example, the recipes of paella and arroz frito (fried rice) arestaples, qualified only as being 'Cuban versions of ... ${ }^{\text {'13 }}$

Rice, beans, sweet potatoes, taro, cassava, boiled or fried bananas, pork and beef are some of the main products used in Cuban cooking. These products are combined in soups such as thetraditional potajes which includes black, kidney or white beans boiled with pork or beef bones, or the traditional ajiaco and its newer cousin, the caldosa. The caldosa is a soup madewith cassava, pumpkin, sweet potatoes, corn, different meats from chicken, lamb, beef or pork, and whatever other vegetables and spices areavailable.
In the seasoning of Cuban food, the dishes are highly seasoned, but not spicy hot. Chilli is rarely used in Cuban cuisine, with only a handful of traditional Cuban dishes that require the use of chilli or pepper. Instead, the seasoning of Cuban dishes uses salt, lime, sour orange, garlic, onion, tomatoes, capsicum, roasted cumin, bay leaves, vinegar and cilantro in any combination. From these spices, salt seems to be the most important because of the popular belief that the salt is the ultimate ingredient which gives or reinforces the flavour of any dish.

If salt is appreciated, sugar is adored. Sugar, one of the main cash crops of the Cuban economy, is one of themost loved components in Cuban cuisine. Its use is considered a must in black coffee, fruit juices and marmalades. Cuban people enjoy drinking guarapo (sugar canejuice), guarapiña (fermented pineapple juice), extra sweet orange juice and bananas, sapotes and sweet mango milkshakes. The Cuban cuisine has a marmaladerecipefor nearly every tropical fruit availablein the island. The most popular ones are those prepared from coconut, guava, mango and pawpaw. They areusually served on their own or with (preferably white) cheese.

Based on this brief overview, it is easy to understand how relatively easy it has been for Cuban migrants in Sydney to reconstruct and maintain their former eating habits. Of course, like all the other migrant groups, they are not able to find some particular products or, in some cases, a product with precisely the 'right flavour', but this is changing. ${ }^{14}$ This can be appreciated in the words of one participant:

In the beginning, it was very difficult to find spices for cooking. You couldn't get cumin, garlic, bay leaves, so to get the Cuban 
flavour in a dish was areal challenge. Now it is much better, but it's still not the same. For example, thechorizos herearenot moist like they used to be in Cuba. The chorizos from 'El Miño', their tastewasvery different. You are lucky now we have nearly everything [for cooking] here.

A further aspect emerging from my fieldwork is that the Cuban migrants of the older generation were al most al ways keen to emphasise that, when they arrived, they needed to get some products from specific places. For example, one person told me that she used to travel from the Western suburbs of Sydney to Bondi, to buy black beans and garlic. Some of the migrants also started to grow some plants themselves, including lime trees, aj i cachucha (a sweeter version of chilli habañero), and even sugar cane. Additionally, among some of them the notion of preserving these plants was very preciously observed. For example, sugar cane is grown in Cuba, but it is not a common backyard plant. Here, some Cuban migrants havea sugar caneclump in their backyards. The variety that is most widely planted is called M edia Luna (Half Moon). One Cuban man told me, while I was admiring his sugar cane plants:

You know that the Cuban government stopped planting M edia Luna in Cuba. They said that it was not profitable, that it didn't produce as much sugar as they expected, so it stopped being produced on a large scale. I don't agree with them. M edia Luna is very niceand sweet, you will try it. So we have been conserving ithere! I will giveyou a bit [of sugar cane], you need to plant it too!

The words express the informant's pride at saving this sugar cane variety, which was not considered sufficiently productive back in Cuba. Underlying these expressions, however, were deeper sentiments. To have a sugar cane clump in your A ustralian backyard is Cuban, but to have a variety discarded by the government from which he fled is seen to have even more prestige. While there is much nostalgia, and an effort to reconstruct those familiar flavours here in Australia, this example takes on a political dimension.

In recounting their life experiences in A ustralia, these Cuban migrants also tend to highlight that the increased migration from different places around the world has been very useful to them in relation to food. This can be seen in these comments abouthow and when they find a product which resembles or is 'nearly Cuban' in flavour, taste or appearance.

I remember that when wearrived you could hardly get an avocado or bananas, even garlic or black beans. Today all thesethings areavailablehere, thanks to migration. Take for example the cassava. It started to be imported from thePacific for the Islanders. I found that theFijian [cassava] is thebest. It tastes like cassava in Cuba. The Indonesian cassava is not very good. The same with the taro, the frozen one has a better quality and valuefor money.

Señora, this [Italian] bread is theclosest one to the pan duro [crusty bread] in Cuba. It is very nice. Wealways get itfrom theltalians, they make it by hand. The Vietnamese bakery sells good bread, but it doesn't last long, and it becomessoggy thenext day. The Italian oneis theclosest bread that wehave found to the Cuban pan duro. It is very crispy likein Cuba.

I get the coffee from a Lebanese shop in Fairfield. They roast it on the spot. Carlos 
also swears that this is the closest coffee roasting to the Cuban counterpart that he had been able to find here in the Western suburbs of Sydney.

At this point the informant brought me the coffee jar and the grinder to smell it. After that he remarked again that the roasting is dark like in Cuba'.

These accounts provide examples of how this group of Cuban migrants has used the increasingly wide offerings of the Sydney ethnic food market to reconstruct their cuisineand maintain the flavour of their beloved Cuban dishes in their everyday lives. Some scholars have criticised the way in which cultural expressions such as food and dance are used as the 'acceptable face of multiculturalism'. ${ }^{15}$ However, in this study, the expansion of the ethnic food market has clearly involved a positive dimension. Indeed, it shows another aspect of Australian multiculturalism, in that a small community is able to reconstruct and maintain a distinct identity, in part, through using some of the conditions facilitated by numerically larger groups. Thus during the last thirty years this group of Cuban migrants has been picking and choosing different products from the Italian, Lebanese, Latin American, Spanish, Asian, African and Pacific Islander shopsto reconstruct their Cuban cuisineand, in turn, their sense of Cuban identity.

Cuban food has not yet entered the public domain of multicultural Australia, as has happened with other aspects of Cuban culture, the most notable being forms of Cuban music and dancing such as salsa. Up to the present, Cuban food in Australia can only befound in household settings, or in some activities organised by other Latin American communities.
This situation may well change in the future. The culinary curiosity of the Australian public continues to expand, reflected in television programs that have overviewed Cuban cuisine several times via some international chefs. In June 2000 the SBS program, 'The Food Lovers' Guide to Australia', dedicated one of its programs to Cuban cuisine by visiting Cuban migrants resident in Sydney and sharing a meal with them. One of the participants in the program, Nancy Sanchez, offered a recipe of congri (a traditional rice and black bean dish) for the viewing public.

\section{CONCLUSION}

This research demonstrates that for this group of Cuban migrants, who havelived in A ustralia for nearly three decades, the maintenance of their previous eating habits and customs constitutes a significant aspect of their construction and re-creation of their original Cuban (national) identity. The importance of food in this construction of identity was well illustrated in the informants' use of eating habits and the serving of food as a way of questioning somebody's 'Cubanness'. For these informants, to be 'Cuban' had many implications for food: its content, preparation, serving and consumption.

In addition, the experience of the Cuban informants highlights a very positive outcome of multiculturalism in A ustralia, as expressed through food. The possibilities for the numerically small Cuban community to access 'national' foods, viaa larger and diverseethnicfood market in Sydney, was essential to their maintenance of their previous diet and, in turn, their sense of Cuban identity. In this way the outcomes of Australia's 
multiculturalism, through food markets, work to facilitate relatively small ethnic groups maintaining their identity in the diversity of multicultural society.

\section{ENDNOTES}

1 I am indebted to many Cuban and Latin American migrants for their stories, hospitality and good humour. Although they arenot willing to recognisethat their accountsareimportant, they represent their lifein a new country. Referencesto names have been changed to protect their identity. I would al so liketo thank my supervisor, Dr. Michael Goddard, for his continuous support in how to use anthropological data. Finally, I want to thank Tom Griffiths for hel ping mewith thetitleand other English language endeavours.

2 Cassava is a native plant of the tropical part of theAmerican continent. Themost popular varieties in Cubaarecrystal, sweet, sour, yellow and Cartagena. However, yellow cassava is mostly planted by small farmers, so its distribution is not very widespread. Purplebanana isa variety of the M usa R osacea and used to be planted too by small-scale farmers in Cuba (see Tomas Roig, 1953, Diccionario Botánico de N ombres V ulgares Cubanos, (Havana: Seoane, Fernandez y Cia) pp. 798, 959.

3 The majority of Cuban migrants have settled in the United States (1043992), with significant populations in Puerto Rico (20000) and Spain (between 12000 and 15000). C. Martin, 'AI Rescate De La Subjetividad: Los Estudios Sobre La Emigración' (The Rescue of Subjectivity: Studies A bout Emigration), in Temas, vol. 1, 1995, pp. 50-56.

4 M.C. García, H avana U SA: Cuban exiles and Cuban Americans in South Florida, 1959-1994, (Berkeley: University of California Press, 1996).

5 García, H avana U SA, p. 73.
6 A. Horin, 'Trouble A mong Those Reluctant Cubans', N ational Times, 31 August-6 September 1980, p. 18.

7 NSW Government, The People of N SW: Statistics from the 1996 Census by the Ethnic A ffairs Commission of N SW, (Sydney:GovernmentPrinter, 1997) p. 2.

8 Ghassan Hage, 'At Homeln TheEntrails OfTheWest: Multiculturalism, "Ethnic food" A nd Migrant Homebuilding', in H . Grace, G. Hage, L. Johnson, M. Langsworth and M. Symonds, eds, H ome/W orld: Space, Community and M arginality in Sydney's West, (Sydney: Pluto Press, 1997, 99-153) p. 108.

9 Hage, 'AtHomein theEntrails', p. 108.

10 Hage, 'AtHomein theEntrails', p. 108.

11 A. Portes \& R.L. Bach, Latin J ourney: Cuban and $M$ exican immigrants in the U nited States, (Berkeley: University of CaliforniaPress, Ltd., 1985).

12 SeeSneja Gunew, 'Feminism and the Politics of IrreducibleDifferences: Multiculturalism/ Ethnicity/ Race', in S. Gunew and A. Yeatman, Feminism and the Politics of D ifference, eds, (St Leonards: Allen \& Unwin, 1993, pp. 1-19).

13 N. Villapol, Cocina Cubana (The Cuban Cuisine), (Havana: Editorial CientíficoTécnica, 1985) pp. 34, 38.

14 For example, see Hage, 'At Home in the Entrails', pp. 108-110.

15 SnejaGunew, 'A gainst Multiculturalism: Rhetorical Images' in G.L. Clark, D. Forbes and R. Francis, M ulticulturalism, Difference and Postmodernism, (Melbourne: Longman Cheshire, 1993, pp. 38-53). 